\title{
Does Glycogen Accumulation in Pancreatic Islet Beta Cells Play a Minor or Major Role in the Physiology and Pathology of the Insulin Secretory Response to Glucose?
}

\author{
Willy J. Malaisse
}

\begin{abstract}
The role of beta cell glycogen in the control of glucose homeostasis was recently questioned. This review aims at reminding that glycogen accumulation in insulin-producing pancreatic islet cells was previously proposed to play a role in the phenomenon of beta cell glucotoxicity. The findings recently reported in an article published in Diabetologia do not invalidate the concept mentioned above.
\end{abstract}

Keywords: Glycogen; Pancreatic beta cells; Insulin secretion

\section{Introduction}

In the title of an article recently published in Diabetologia, it is stated that "genetic models rule out a major role of beta cell glycogen in the control of glucose homeostasis" [1]. In a letter concerning this article and also published in Diabetologia [2], it was reminded, however, that a role for glycogenolysis in pancreatic beta cells in the regulation of insulin secretion was first proposed in 1967, when it was observed that theophylline stimulates insulin secretion from pancreatic pieces incubated in the absence of extracellular glucose, provided that the pieces of pancreas were obtained from rats infused for $8-10 \mathrm{~h}$ with glucose, whilst such was not the case in pancreatic pieces prepared from euglycemic control rats [3]. The glucose-infused animals were severely hyperglycemic (mean plasma glucose concentration $72 \mathrm{mM}$ ) and fine particles of glycogen were histologically demonstrated in their islets. In the pieces of pancreas removed from the hyperglycemic rats and incubated in the absence of glucose, the enhancing action of theophylline (1.4 $\mathrm{mM}$ ) upon insulin output was unaffected by mannoheptulose, which inhibits glucose phosphorylation, but was opposed by 2-deoxyglucose, which competitively inhibits isomerization of glucose-6-phosphate to fructose-6-phosphate and, by doing

Manuscript accepted for publication August 19, 2016

Department of Biochemistry, Universite Libre de Bruxelles, 808 Route de Lennik, B-1070 Brussels, Belgium. Email: malaisse@ulb.ac.be

doi: http://dx.doi.org/10.14740/jem368w so, decreases glycolysis. It was later duly documented that, in rat islets preincubated for $20 \mathrm{~h}$ in the presence of $83.3 \mathrm{mM}$ glucose and, hence, containing large amounts of glycogen (76 \pm 12 pmol of glucose residue per islet), whilst no significant amount of glycogen was detected in the islets prior to preincubation, theophylline stimulates insulin release, accelerates the rate of glycogenolysis, augments lactate output and increases ${ }^{14} \mathrm{CO}_{2}$ production by islets preincubated at the high glucose concentration in the presence of D-(U- $\left.{ }^{14} \mathrm{C}\right)$ glucose [4]. Moreover, both in the absence or presence of theophylline, the fall in glycogen content during a final 30-min incubation was closely matched by the amount of carbon appearing as either lactate or ${ }^{14} \mathrm{CO}_{2}$.

\section{Beta Cell Glycogen and Glucotoxicity}

More importantly in the perspective of diabetology, the accumulation of glycogen in insulin-producing cells was then proposed to account for two typical features of the phenomenon of beta cell glucotoxicity in non-insulin-dependent diabetic subjects, i.e. the paradoxical early inhibition of insulin output in response to the intravenous administration of glucose and the perturbed anomeric specificity of the beta cell secretory response to glucose [5].

A paradoxical decrease in insulinemia after intravenous administration of glucose $(0.3-0.5 \mathrm{~g} / \mathrm{kg}$ body weight) was first observed in non-insulin-dependent diabetic subjects [6]. The lowest insulinemia recorded in 14 subjects was $3.0 \pm 1.2$ $\mu \mathrm{U} / \mathrm{mL}$ lower $(\mathrm{P}<0.03)$ than the paired basal value $(13.0 \pm 2.1$ $\mu \mathrm{U} / \mathrm{mL}$ ). In control normoglycemic subjects examined under the same experimental conditions, a significant increase in insulinemia $(+9.1 \pm 3.1 \mu \mathrm{U} / \mathrm{mL})$ above paired basal value $(4.7 \pm$ $0.7 \mu \mathrm{U} / \mathrm{mL}$ ) was already observed 1 min after glucose administration, such an increment reaching a mean value of $+34.8 \pm$ $7.6 \mu \mathrm{U} / \mathrm{mL}$ between the third and fifth minute of the test. After completion of the first 60 -min intravenous glucose tolerance test, the 14 non-insulin-dependent diabetic subjects were treated for $24 \mathrm{~h}$ with insulin infused intravenously. Over the last 22 $\mathrm{h}$ of such an infusion, the glycemia remained close to $5.6 \mathrm{mM}$, as compared to a fasting plasma glucose concentration of 12.8 $\pm 0.8 \mathrm{mM}$ before the first test, itself conducted in the diabetic patients deprived of oral therapy during the last 3 days before such a first test. After the intravenous infusion of insulin, a sec- 
ond intravenous glucose tolerance test was initiated $1 \mathrm{~h}$ after interruption of insulin administration. At 1, 3 and 5 min of this second test, the increment in insulinemia above paired basal value averaged in the 14 diabetic subjects $8.9 \pm 2.8,7.0 \pm 3.0$ and $4.4 \pm 1.1 \mu \mathrm{U} / \mathrm{mL}$ [6]. In a further study, an improvement by insulin treatment of the early phase of glucose-stimulated release was still observed in six non-insulin-dependent diabetic subjects when the second intravenous glucose tolerance test was performed after a rapid restoration of hyperglycemia. In the latter experiments, the glycemia averaged $5.4 \pm 0.6 \mathrm{mM}$ after the 22-h insulin infusion and was brought back to 12.4 $\pm 1.1 \mathrm{mM}$ after $39 \pm 5 \mathrm{~min}$ intravenous administration of a solution of glucose $(0.55 \mathrm{~mol} / \mathrm{L})$ [7]. Paradoxical insulin secretory responses to changes in extracellular glucose concentration were also observed in perfused pancreases removed from rats infused for $48 \mathrm{~h}$ with a hypertonic solution of glucose. In these rats, the plasma glucose concentration eventually averaged prior to anesthesia $20.4 \pm 4.4 \mathrm{mM}$, as compared to $8.3 \pm$ $0.3 \mathrm{mM}$ in control rats. The glycogen content of isolated pancreatic islets amounted to $41.9 \pm 10.8 \mathrm{pmol}$ of glucose residue per islet in the glucose-infused rats, as compared to $1.2 \pm 0.9$ pmol/islet in the control animals [8].

Likewise, a perturbation of the anomeric specificity of the beta cell secretory response to glucose was first documented in some non-insulin-dependent diabetic subjects selected for moderate post-absorptive hyperglycemia (plasma glucose concentration $\leq 9.2 \mathrm{mM}$ ) [9]. In 15 healthy volunteers with no family history of diabetes, the paired $\alpha / \beta$ ratio for the plasma insulin concentration (expressed relative to paired basal value) averaged, in fair agreement with a prior study [10], 1.61 $\pm 0.31(\mathrm{P}<0.05$ versus unity), $1.30 \pm 0.13$ and $1.16 \pm 0.09$ ( $\mathrm{n}=15$ in all cases) 2,4 and $6 \mathrm{~min}$ after injection of either 3.5 or $5.0 \mathrm{~g}$ of each anomer. Out of 13 non-insulin-dependent subjects, selected on the basis of mild fasting hyperglycemia, eight patients failed to display a sufficient increase in plasma insulin concentration to allow any comparison between the response to $\alpha$ - and $\beta$-D-glucose. As judged from either basal plasma glucose or insulin concentration, these eight subjects were the most severely diabetic. In the remaining five subjects, the highest plasma insulin concentration reached after administration of D-glucose corresponded to no more than a $70 \%$ increase above basal value, as distinct from the four- to five-fold increase seen in normal subjects. Moreover, the secretory response to glucose occurred more slowly in diabetic than normal subjects, such a delayed response representing a further unfavorable attribute for investigating the anomeric specificity of insulin release in view of the rapid interconversion of D-glucose anomers at $37^{\circ} \mathrm{C}$. Despite these limitations, a preferential $\alpha$-stereospecific response, similar to that seen in normal subjects, was identified in three diabetic patients, whilst such was not the case in the last two diabetic subjects. It was proposed that a possible perturbation in certain diabetic subjects of the preferential response to $\alpha$-D-glucose found in normal subjects warranted more extensive investigation on its presence and etiopathogenic significance [9]. An obvious perturbation of the anomeric specificity of the insulin secretory response to glucose was then observed in rats injected with streptozotocin during the neonatal period [11] and by comparison of 13 normoglycemic and 11 diabetic BB rats of compara- ble age and body weight [12]. Likewise, at variance with the more pronounced insulin secretory response to $\alpha$ - as compared to $\beta$-D-glucose found in control rabbits, in rabbits with ductligated pancreas, the insulin secretory response to $\alpha$-D-glucose became either comparable to that evoked by $\beta$-D-glucose in euglycemic duct-ligated rabbits or significantly lower than that provoked by the $\beta$-anomer in hyperglycemic duct-ligated rabbits [13]. Even in normal rats rendered mildly hyperglycemic by oral administration of diazoxide for $48 \mathrm{~h}$, the $\alpha / \beta$ ratio in insulin output was twice lower than in control rats [14]. The anomeric specificity of glucose-induced insulin release was preserved, however, in euglycemic rats examined 48 - 211 days after partial pancreatectomy (removal of $80-85 \%$ of the pancreas) [15] or in rats starved for 2 days [16], suggesting that the anomeric malaise may be attributable to hyperglycemia rather than either beta cell secretory hyperactivity as occurring in pancreatectomized rats or a decreased rate of D-glucose utilization by beta cells, as indeed observed in starved rats [17].

The metabolic determinants of the paradoxical changes in insulin secretion in response to a rise or fall in extracellular glucose concentration were eventually identified as follows. Pancreatic islets were isolated from rats infused for $48-72 \mathrm{~h}$ with a hypertonic solution of glucose. The glycogen content of these islets averaged $36.6 \pm 9.0$ pmol of glucose equivalent per islet $(n=30)$. When such islets were incubated for two successive periods of $10 \mathrm{~min}$ each, in the presence first of 16.7 $\mathrm{mM}$ and then $\left.2.8 \mathrm{mM} \mathrm{D-(U-}{ }^{14} \mathrm{C}\right)$ glucose, the total output of L-lactic acid during the second incubation was as high as that recorded during the first incubation, while the specific radioactivity of L-lactic acid dramatically decreased during the second incubation. In islets from normoglycemic rats, however, the total output of L-lactic acid decreased and its specific radioactivity modestly increased as the concentration of D-glucose was lowered from 16.7 to $2.8 \mathrm{mM}$. Such contrasting results indicate that, in the glycogen-rich islets isolated from glucose-infused rats, the fall in extracellular D-glucose concentration was not accompanied by a parallel fall in glycolytic flux, the decreased utilization of exogenous D-(U- $\left.{ }^{14} \mathrm{C}\right)$ glucose coinciding with stimulation of glycogenolysis. This unusual metabolic situation also coincided with a transient and paradoxical stimulation of insulin release in response to the decrease in extracellular D-glucose concentration [18]. Incidentally, it was first documented that, in rat islets cultured for $48 \mathrm{~h}$ at high D-glucose concentration $(20 \mathrm{mM})$ and then incubated for $6 \mathrm{~min}$ in the absence or presence of D-glucose $(7$ $\mathrm{mM})$, the rate of glycogenolysis as judged from the generation of ${ }^{3} \mathrm{HOH}$ by islets first cultured in the presence of $\mathrm{D}-\left(5-{ }^{3} \mathrm{H}\right)$ glucose was higher in the islets eventually incubated in the absence of glucose $(0.90 \pm 0.15 \mathrm{pmol} /$ islet $)$ as distinct $(\mathrm{P}<0.01)$ from presence of glucose $(0.37 \pm 0.06 \mathrm{pmol} /$ islet $)$ [19]. In the light of these findings, it was proposed that the interference of glycogenolysis with glycolysis participates in the paradoxical changes of the secretory response to glucose, considered as a feature of beta cell glucotoxicity. The regulation by the glucose anomers of glycogenolysis in glycogen-rich islets was not ignored. In rat islets cultured for $48 \mathrm{~h}$ in the presence of either D-(U- $\left.{ }^{14} \mathrm{C}\right)$ glucose or D- $\left(5-{ }^{3} \mathrm{H}\right)$ glucose, the extent of glycogen accumulation, which was virtually identical with these two radioactive tracers, was twice higher in islets cultured in 
the presence of $40 \mathrm{mM}$ as distinct from $20 \mathrm{mM}$ of the hexose. When D- $\left(5-{ }^{3} \mathrm{H}\right)$ glucose was present in the culture medium, the generation of ${ }^{3} \mathrm{HOH}$ from tritiated precursors, e.g. glycogen, during a final 6-min incubation at $37{ }^{\circ} \mathrm{C}$, was much higher when such a final incubation was conducted in the absence of exogenous glucose, as distinct from either $\alpha$ - or $\beta$-D-glucose $(7.0 \mathrm{mM})$. When either the $\alpha$ - or $\beta$-anomer of $\mathrm{D}-\left(5-{ }^{3} \mathrm{H}\right) \mathrm{glu}$ cose was present in the incubation medium only during the final 6-min incubation, the generation of ${ }^{3} \mathrm{HOH}$ attributable to the catabolism of the exogenous tritiated anomer could also be assessed. On average, the ratio between exogenous D- $\left(5-{ }^{3} \mathrm{H}\right)$ glucose utilization during the last 6-min incubation and endogenous ${ }^{3} \mathrm{HOH}$ production during the same 6-min incubation after culture of the islets for $48 \mathrm{~h}$ in the presence of D-glucose $(20 \mathrm{mM})$ mixed with a tracer amount of D- $\left(5-{ }^{3} \mathrm{H}\right)$ glucose was twice higher in the islets eventually exposed to $\alpha$ - as distinct from $\beta$-D-glucose [19]. Such a situation was then attributed to the anomeric specificity of the interaction of phosphorylase a with $\mathrm{D}$-glucose. It was indeed documented that $\alpha$-D-glucose is more potent than $\beta$-D-glucose in causing either inhibition of phosphorylase a or inactivation of phosphorylase by phosphorylase phosphatase [20].

In the light of these findings, a mathematical model was eventually proposed to account for both the paradoxical decrease in insulin output and so-called anomeric malaise in noninsulin-dependent diabetic subjects [5].

Because of the limit of about 1,500 words imposed on the writing of a "Letter" in Diabetologia, all relevant comments on the findings reported by Mir-Coll et al [1] could not be explicitely presented or even only mentioned in such a letter [2].

\section{Recent Findings}

Three series of experiments were performed by Mir-Coll et al to document their assertions that glycogen metabolism in beta cells is not required for the maintenance of beta cell function and that glycogen accumulation in beta cells is not sufficient to trigger the dysfunction of these cells.

The first set of investigations concerns a model of mice with pancreas-specific knockout of glycogen synthase (Gys $1{ }^{\mathrm{KO}}$ mice). As an initial step, the muscle glycogen synthase isoform Gys1, but not the liver isoform Gys2, transcripts were detected in rodent islet beta cells. Correlating with these mRNA data, muscle glycogen synthase, but not liver glycogen synthase, was found in total pancreatic extracts from rat islets. In isolated islets from Gys $1^{\mathrm{KO}}$ mice, Gys1 mRNA was reduced by $85 \%$ and protein undetectable by Western blot. The metabolic data indicated that, at 12 weeks of age, the body weight, the glycemia and insulinemia found after overnight fast and during an intraperitoneal glucose tolerance test, as well as the islet insulin content and the release of insulin from islets incubated for $60 \mathrm{~min}$ at either 2.8 or $16.7 \mathrm{mM}$ glucose, all failed to differ significantly in the Gys $1{ }^{\mathrm{KO}}$ mice and the control animals. Likewise, the relative expression of functionally relevant genes, e.g. Glut2, Gck (glucokinase) and Ins1/Ins2, was unchanged in the Gys $1^{\mathrm{KO}}$ islets. Furthermore, 45 -week-old Gys $1^{\mathrm{KO}}$ mice continued to exhibit mean body weight and glycemia during an intraperitoneal glucose tolerance test performed after overnight fasting similar to those found in age-matched control mice. Although the islet glycogen content was apparently not measured in the Gys $1^{\mathrm{KO}}$ mice, it was concluded that glycogen metabolism is not required for adequate beta cell function and glucose homeostasis under physiological conditions. Such a view is in agreement with prior findings, since the islets of normal rats contain virtually no glycogen $(1.2 \pm 0.9$ pmol of glucose residue per islet; $\mathrm{n}=3$ ) and are indeed currently used as control in metabolic and functional studies [8]. One could feel sorry that advantage was not taken from this first animal model to find out whether Gys $1^{\mathrm{KO}}$ mice would be protected, under suitable experimental conditions, against beta cell glucotoxicity. For instance, pancreatic islets from Gys $1^{\mathrm{KO}}$ mice and corresponding control mice could be either obtained from animals first perifused for $48 \mathrm{~h}$ with a hypertonic solution of glucose or first cultured for $48 \mathrm{~h}$ at a high glucose concentration. The islets could then be perifused and exposed during perifusion to a sudden decrease in extracellular glucose concentration, e.g. from 16.7 to $2.8 \mathrm{mM}$. Under these experimental conditions, a paradoxical transient increase in insulin output in response to the lowering of extracellular glucose concentration would be expected to occur in the islets prepared from the control mice. However, because of the absence of glycogen accumulation in the islets from Gys $1^{\mathrm{KO}}$ mice, the same decrease in extracellular glucose concentration should provoke an immediate and sustained decrease of insulin release.

The second set of experiments was conducted in a transgenic model overexpressing in beta cell the scaffolding protein acting as a hub between glycogen synthase, protein phosphatase 1 and glycogen in promoting glycogen synthesis. To drive the expression of protein targeting to glycogen (PTG) to beta cells, mice conditionally expressing the coding sequence of the protein phosphatase 1 regulatory subunit $3 \mathrm{C}(\mathrm{Ppp} 1 \mathrm{r} 3 \mathrm{c})$ on the action of Cre recombinase were crossed with rat insulin II promoter (RIP)-cre mice. When compared to RIP-cre mice used as controls, isolated pancreatic islets of this overexpressing model $\left(\mathrm{PTG}^{\mathrm{OE}}\right)$ displayed a 30 -fold increase in mRNA levels of Ppp1r3c and 3.5-fold higher glycogen levels in islets freshly isolated from fed animals. In mice fasted overnight, glycogen levels in freshly isolated islets were negligible both in $\mathrm{PTG}^{\mathrm{OE}}$ and control mice. The regulation of glycogen accumulation in beta cells of $\mathrm{PTG}^{\mathrm{OE}}$ mice was further documented by comparison of the glycogen content in islets obtained from fed rats and cultured for $24 \mathrm{~h}$ at either low $(5 \mathrm{mM})$ or high $(25$ $\mathrm{mM})$ glucose concentration. The glycogen levels were almost undetectable in islets from both $\mathrm{PTG}^{\mathrm{OE}}$ and control mice after culture at the low glucose concentration, whilst being about 6.4 times higher in islets from $\mathrm{PTG}^{\mathrm{OE}}$ mice (about $15 \mathrm{ng}$ /islet) as distinct from control mice (about $2 \mathrm{ng} /$ islet) after culture at the high glucose concentration.

Incidentally, no information was provided on the volume of the isolated islets. Nevertheless, the following considerations suggest that such a volume was comparable to that of islets freshly prepared from normal rats. Thus, the "representative" images of the pancreas illustrated in fig. $5 \mathrm{f}$ [1] concern cross-sections of islets with a diameter close to $150-190 \mu \mathrm{m}$. On average, this would correspond to a cross-section area close to $23,000 \mu \mathrm{m}^{2}$, indicating that, as expected from the usual pro- 
cedure for isolation of pancreatic islets, these islets belonged to the close to $15 \%$ larger islets with an area in excess of 5,000 $\mu \mathrm{m}^{2}$ (fig. 5c [1]). Even if assuming that the representative images in fig. $5 \mathrm{f}[1]$ correspond to equatorial sections of spheric islets, their volume would amount to at least $2.6 \mathrm{~nL}$, indeed in fair agreement with the total volume (intracellular and extracellular space) of rat islets [8]. Likewise, the glycogen content of freshly isolated islets prepared from control mice, i.e. about $1.5 \mathrm{ng} /$ islet (fig. 3b [1]) was somewhat higher, albeit not necessarily incompatible, with that found in islets prepared from euglycemic rats. Thus, in terms of glucose residue, 1.5 $\mathrm{ng} /$ islet correspond to about $9 \mathrm{pmol} / \mathrm{islet}$, as compared to 1.2 $\pm 0.9 \mathrm{pmol} /$ islet in islets prepared from euglycemic rats [8]. In this respect, it should be kept in mind that a species difference between rat and mouse consists in the fact that, relative to the maximal secretory rate recorded in vitro at $55.6 \mathrm{mM}$ D-glucose, the basal insulin output found in the absence of glucose is much higher in mouse than in rat pancreas pieces [21], possibly suggesting a contribution of islet cell glycogenolysis to the basal release of insulin from mouse endocrine pancreas.

At 6 weeks of age, no difference between control and transgenic PTG ${ }^{\mathrm{OE}}$ mice was found in terms of beta cell mass, beta cell size, islet size distribution and alpha cell mass. At 60 weeks of age, the beta cell mass was also comparable in control and $\mathrm{PTG}^{\mathrm{OE}}$ mice. In terms of glucose homeostasis, the body weight, the glycemic pattern during an intraperitoneal glucose tolerance test, the insulin content of the islets, the secretion of insulin by freshly isolated islets incubated for 90 $\mathrm{min}$ in the sole presence of either 2.3 or $16.7 \mathrm{mM}$ D-glucose or combined presence of $16.7 \mathrm{mM}$ D-glucose and $10.0 \mu \mathrm{M}$ forskolin and expressed relative to the islet insulin content and the relative expression (mRNA level) of genes essential for sustaining beta cell function (Glut2, Gck, Ins1/Ins2) all failed to differ significantly in control and $\mathrm{PTG}^{\mathrm{OE}}$ mice examined at 14 weeks of age. Even at 55 - 60 weeks of age, the body weight and glycemic pattern during an intraperitoneal glucose tolerance test performed after overnight starvation were virtually identical in $\mathrm{PTG}^{\mathrm{OE}}$ and control mice.

The last set of experiments concerned the possible effects of a high fat diet, considered as a stress condition, in the two transgenic models. The sole significant change consisted in the fact that, after 16 weeks on the high fat diet, Gys $1^{\mathrm{KO}}$ mice weighed more, had increased fasting glycemia and insulinemia and showed worsened glucose tolerance during an intraperitoneal test, when compared to control mice. The worsened glucose tolerance was proposed to be related to exacerbated insulin resistance.

Conceptually, the experiments conducted in $\mathrm{PTG}^{\mathrm{OE}}$ mice are quite relevant to the major issue of the present article, i.e. the possible consequence of excessive glycogen accumulation in beta cells on their functional behavior. In such a perspective, the blood insulin measurements during the intraperitoneal glucose tolerance test are not contributive since this test was conducted after overnight fast, i.e. at a time when the islet glycogen content is negligible in either control or $\mathrm{PTG}^{\mathrm{OE}}$ mice. As a matter of fact, the data concerning insulinemia during the intraperitoneal glucose tolerance test raise serious concern. Thus, in the $\mathrm{PTG}^{\mathrm{OE}}$ mice, a trend towards a lower insulinemia at $30 \mathrm{~min}$ then at $0 \mathrm{~min}$ of the test was observed. Even in the corresponding control mice, no significant increase in insulinemia above basal value was recorded at the $30 \mathrm{~min}$ of the test, i.e. at a time when insulinemia otherwise reaches its peak value under identical experimental conditions (intraperitoneal administration of $2 \mathrm{~g}$ glucose $/ \mathrm{kg}$ body weight) in normal mice [22]. In such a respect, Mir-Coll et al refer to a prior publication in which it was documented that, at least in hepatocytes, PTG modifies the phosphorylation and activity of glycogen phosphorylase. Could one question the suitability of $\mathrm{PTG}^{\mathrm{OE}}$ mice to assess the role of beta cell glycogenolysis in the control of glucose homeostasis?

Once again, conceptually, the measurements of insulin secretion by freshly isolated islets incubated for 90 min could provide more relevant information. However, the design of these experiments raises serious concern. First, it is not clear whether the islets were obtained from fed or fasted mice. Second, according to the information indicated by Mir-Coll et al in the Methods section of their article for in vitro insulin secretion, the islets are first (pre)incubated for $30 \mathrm{~min}$ in the presence of $2.8 \mathrm{mM}$ glucose. Third, no information is provided on the glycogen content of the islets as measured immediately after isolation and/or at the end of the first $30 \mathrm{~min}$ period of exposure to the low concentration of glucose. Likewise, no information is provided on the time course of the beta cell secretory response to changes in extracellular glucose concentration. Last, the most relevant experiment concerning the possible role of beta cell glycogen in the secretory response to glucose, i.e. the assessment of the effect of forskolin upon insulin release by islets incubated at a low concentration of glucose, was not performed. Thus, if freshly isolated islets obtained from fed $\mathrm{PTG}^{\mathrm{OE}}$ mice had been immediately after isolation (i.e. in the absence of any preincubation) incubated for a relatively short period (e.g. $30 \mathrm{~min}$ or less) at a low concentration of glucose (e.g. $2.8 \mathrm{mM}$ or even in the absence of glucose), forskolin would be expected to increase insulin output (relative to the value found under the same experimental condition in the absence of forskolin), whilst such would not be the case in the islets from control mice. And yet, it cannot be ignored that in the discussion of the article contributed by the Barcelona investigators, they nevertheless speculate that glycogenolysis in beta cells of $\mathrm{PTG}^{\mathrm{OE}}$ mice after an overnight fast may stimulate insulin release and explain increased insulin levels when these animals are subjected to fasting. Hence, a role for beta cell glycogen in the control of glucose homeostasis is not totally ruled out.

A last remark before concluding: A paradoxical insulin secretory response to glucose may occur independently of glycogen accumulation. For instance, a rise in glucose concentration may provoke a rapid inhibition of insulin release from islets exposed to the neurotransmitter dopamine [23].

Meanwhile, it seems still correct to incriminate glycogen accumulation in pancreatic insulin-producing cells as a key determinant of the phenomenon of beta cell glucotoxicity.

\section{Funding}

This work was not supported by any funding. 


\section{Disclosure}

The author has nothing to declare.

\section{Abbreviations}

Gys ${ }^{\mathrm{KO}}{ }^{\mathrm{K}}$ Gys1 knockout; PTG: protein targeting to glycogen.

\section{References}

1. Mir-Coll J, Duran J, Slebe F, Garcia-Rocha M, Gomis R, Gasa R, Guinovart JJ. Genetic models rule out a major role of beta cell glycogen in the control of glucose homeostasis. Diabetologia. 2016;59(5):1012-1020.

2. Malaisse WJ. Role of glycogen metabolism in pancreatic islet beta cell function. Diabetologia. 2016; in press.

3. Malaisse WJ, Malaisse-Lagae F, Mayhew D. A possible role for the adenylcyclase system in insulin secretion. J Clin Invest. 1967;46(11):1724-1734.

4. Malaisse WJ, Sener A, Koser M, Ravazzola M, Malaisse-Lagae F. The stimulus-secretion coupling of glucose-induced insulin release. Insulin release due to glycogenolysis in glucose-deprived islets. Biochem J. 1977;164(2):447-454.

5. Malaisse WJ. Physiology of insulin secretion and its alteration in diabetes: the concept of glucotoxicity. In: Andreani D, Gueriguian JL, Striker GE, eds. Diabetic complications: epidemiology and pathogenetic mechanisms. New York: Raven Press, 1991:3-23.

6. Gomis R, Novials A, Coves MJ, Casamitjana R, Malaisse WJ. Suppression by insulin treatment of glucose-induced inhibition of insulin release in non-insulin-dependent diabetics. Diabetes Res Clin Pract. 1989;6(3):191-198.

7. Novials A, Gomis R, Coves MJ, Conget I, Malaisse WJ. Improvement by insulin treatment of the early phase of glucose-stimulated insulin release in non-insulindependent diabetics explored after restoration of hyperglycemia. Med Sci Res. 1989;17:381-382.

8. Marynissen G, Leclercq-Meyer V, Sener A, Malaisse WJ. Perturbation of pancreatic islet function in glucoseinfused rats. Metabolism. 1990;39(1):87-95.

9. Rovira A, Garrote FJ, Valverde I, Malaisse WJ. Anomeric specificity of glucose-induced insulin release in normal and diabetic subjects. Diabetes Res. 1987;5(3):119-124.

10. Rossini AA, Soeldner JS. Insulin release is glucose anomeric specific in the human. J Clin Invest.
1976;57(4):1083-1088.

11. Niki A, Niki H, Niki I, Kunoh Y. Insulin release by glucose anomers in a rat model of non-insulin-dependent diabetes. Diabetologia. 1988;31(1):65-67.

12. Leclercq-Meyer V, Marchand J, Malaisse WJ. Alteration of the insulin secretory response to D-glucose anomers in diabetic BB rats. Med Sci Res. 1987;15:1535-1536.

13. Fichaux F, Marchand J, Yaylali B, Leclercq-Meyer V, Catala J, Malaisse WJ. Altered anomeric specificity of glucose-induced insulin release in rabbits with duct-ligated pancreas. Int J Pancreatol. 1991;8(2):151-167.

14. Leclercq-Meyer V, Marchand J, Malaisse WJ. Attenuated anomeric difference of glucose-induced insulin release in the perfused pancreas of diazoxide-treated rats. Horm Metab Res. 1991;23(6):257-261.

15. Leclercq-Meyer V, Malaisse-Lagae F, Coulic V, Akkan AG, Marchand J, Malaisse WJ. Preservation of the anomeric specificity of glucose-induced insulin release in partially pancreatectomized rats. Diabetologia. 1992;35(6):505-509.

16. Leclercq-Meyer V, Marchand J, Malaisse WJ. Effect of starvation upon the anomeric specificity of glucose-induced insulin release. Diab Nutr Metab. 1993;6:129-134.

17. Levy J, Herchuelz A, Sener A, Malaisse WJ. The stimulus-secretion coupling of glucose-induced insulin release. $\mathrm{XX}$. fasting: a model for altered glucose recognition by the B-cell. Metabolism. 1976;25(5):583-591.

18. Malaisse WJ, Maggetto C, Leclercq-Meyer V, Sener A. Interference of glycogenolysis with glycolysis in pancreatic islets from glucose-infused rats. J Clin Invest. 1993;91(2):432-436.

19. Malaisse WJ, Marynissen G, Sener A. Possible role of glycogen accumulation in B-cell glucotoxicity. Metabolism. 1992;41(8):814-819.

20. Bollen M, Malaisse-Lagae F, Malaisse W, Stalmans W. The interaction of phosphorylase a with D-glucose displays alpha-stereospecificity. Biochim Biophys Acta. 1990;1038(2):141-145.

21. Malaisse W, Malaisse-Lagae F. [Effects of glucose on pancreatic secretion of insulin in vitro, in different species of rodents]. Ann Endocrinol (Paris). 1968;29(4):501505 .

22. Andrikopoulos S, Blair AR, Deluca N, Fam BC, Proietto $\mathrm{J}$. Evaluating the glucose tolerance test in mice. Am J Physiol Endocrinol Metab. 2008;295(6):E1323-1332.

23. Carpinelli AR, Nogueira CR, Machado UF, Curi R, Malaisse WJ. Paradoxical inhibition of insulin release by D-glucose islets exposed to dopamine. Horm Metab Res. 1992;24(9):452-453. 